\title{
The effectiveness of percutaneous injections of ozonotherapy in low back pain
}

\author{
(iD) Luciano Timbó Barbosa ${ }^{1}$ \\ Délio Fernando de Sousa Rodrigues ${ }^{1}$ \\ (iD) Raul Ribeiro de Andrade 2 \\ (iD) Fabiano Timbó Barbosa ${ }^{1}$
}

1. Universidade Federal de Alagoas (Ufal), Maceió, AL, Brasil 2. Centro Universitário Cesmac (Cesmac), Maceió, AL, Brasil

http://dx.doi.org/10.1590/1806-9282.66.8.1146

\section{SUMMARY}

INTRODUCTION: Lumbar pain is one of the main reasons for medical consultation, causing the disruption of daily routines due to its disabling nature, thus resulting in social and personal damage. Among the complementary treatments, ozonotherapy offers analgesia to most patients, with reports of complications. However, great questions about its clinical effectiveness have not been answered yet, and there have been reports of serious complications.

OBJECTIVE: To describe the use of ozonotherapy in the treatment of lumbar pain, focusing on its favorable and unfavorable effects, and its analog profile.

METHODS: A cross-sectional bibliographic research was performed with scientific articles obtained from the Pubmed, LILACS and Scopus database, using the following descriptors: "Ozone", "Therapy", "Lumbar pain", "complication", "Disk herniation", "Guideline", "Protocol", "Standards", "Criteria".

RESULTS: The researched literature corroborates that, in clinical practice, there is safety in the use of oxygen-ozone therapy through percutaneous injections for the treatment of lumbar pain, especially when compared to surgeries and use of medicines, provided that strict criteria are followed.

CONCLUSION: The procedure is effective and has a favorable analgesic profile. However, it is necessary to produce a medical guideline that will help in its strict and systematic control.

KEYWORDS: Ozone/therapeutic use. Low back pain. Spinal cord compression. Intervertebral disc displacement.

\section{INTRODUCTION}

Low back pain is one of the main reasons for medical consultations, hindering the execution of daily activities, due to its incapacitating nature, thus resulting in social and personal expenditures and requiring preventive treatment ${ }^{1-3}$. Among complementary treatments, ozonotherapy has gained greater prominence after its use was authorized in the entire national territory of Brasil by the Senate Bill no. $9,001 / 2017^{4}$. In addition to being little invasive, it is a method that provides analgesia for most patients, 
with minimal reports of complications ${ }^{2,3,5}$. However, important questions regarding its clinical effectiveness remain answered, in addition to some reports of serious complications ${ }^{6}$, which have given cause for a letter by the Federal Council of Medicine (CFM), on 14 December 2017, condemning the bill, alleging lack of technical and scientific evidence of the method's efficacy and safety ${ }^{7}$. However, advanced studies on the treatment of different musculoskeletal disorders, such as rheumatoid arthritis, lumbar facet syndrome, joint syndrome, subacromial bursitis, carpal tunnel syndrome, osteoarthritis, hip bursitis, adhesive capsulitis of the shoulder, temporomandibular disorder, and mainly on the treatment of diseases of the spinal column, make ozonotherapy an option of effective treatment $^{8-10}$.

It is essential to know that around $70-80 \%$ of the world population has low back pain. Among these, the most frequent of radicular compressions is the disc disease, whose spontaneous resolution of pain in the acute phase (from 6 to 12 weeks after the onset of pain) has been documented in $60-80 \%$ of those affected by it, with the ability to resume work activities three months after the onset of symptoms ${ }^{1,5,11}$.

Cases that are not spontaneously resolved are managed by conservative treatments, with good outcomes in $90 \%$ of lumbar pain cases ${ }^{9}$. The procedures are minimally invasive, such as corticosteroid, anti-inflammatory and anesthetic injections, chymopapain chemonucleolysis, nucleo-discectomy, intradiscal laser discectomy, intradiscal electrothermal therapy, percutaneous nucleoplasty, and chemodiscolysis using a mixture of oxygen and ozone $\left(\mathrm{O}_{2} \mathrm{O}_{3}\right)$, the first choice, after the failure of others. The technique is supported by its favorable effects ${ }^{4,12,13}$.

Surgery is performed in cases of intolerable symptoms, progressive neurological deficits, or risk of cauda equina syndrome $\mathrm{e}^{14.15}$.

The whole of the conservative propaedeutics along with minimally invasive procedures conceptualizes complementary treatments for pain relief and accelerated healing ${ }^{3.5}$. The goal of this paper was to describe the use of ozonotherapy in the treatment of lumbar pain, focusing on its favorable e unfavorable effects and analgesic profile.

\section{METHODS}

The bibliographic and transversal search for scientific papers was conducted in the PubMed (maintained by the National Center for Biotechnology Information), Lilacs, and Scopus databases. We used the following keywords: "Ozone”, "Therapy”, "Lumbar Pain," “Complication”, “Herniated Disc”,"Guideline”, “Protocol”, "Patterns", "Criteria". The inclusion criteria were: scientific studies on humans, male or female, aged 18 years or more, diagnosed with lumbar pain. There were no restrictions regarding dates or languages to the publications included. Scientific studies related to the subject were selected after analysis of their titles and abstracts. Papers such as letters to the editor, communications, editorials, commentaries, and studies with partially published data were excluded.

\section{HISTORICAL PERSPECTIVE}

Ozone $\left(\mathrm{O}_{3}\right)$ has been studied for a very long time, its first observer was the philosopher and scientist Martin van Marum, who in 1783 felt a peculiar odor, which he subsequently named the "smell of electricity", near his electrostatic machine whenever it was working ${ }^{16.17}$. Another researcher, Cruickshank, reported the same characteristic smell in $1801^{16.17}$. However, the two only described the smell and did not do ahead with their studies $^{16.17}$. However, a chemistry professor at the University of Basel, Christian Friedrich Schönbein, identified, in 1839, the same smell in water electrolysis and, in 1840 , declared it was a gas, which he called ozone ${ }^{16-}$ ${ }^{19}$. The molecular formula of ozone was determined in 1865 by Jacques-Louis Soret and confirmed in 1867 by Schönbein, who is considered its discoverer ${ }^{16.17}$.

During the First World War, ozone was used for the first time, by Dr. Albert Wolf, as a groundbreaking therapy even in gangrenous injuries, paving the way for its use in medicine $e^{3,13,14,19,20}$.

Subsequently, an attempt to cease lumbar pain using ozonotherapy was made in 1989, by Verga, an orthopedic surgeon who applied gas injections into sensitive areas of the paravertebral muscle, treating approximately 8,000 patients aged over 15 years; the recurrence of pain was less than $2 \%^{\mathbf{1 8}}$. Eight years later, Fabris et al. ${ }^{21}$ published a study reporting a new type of percutaneous treatment for lumbar herniated disc based on intradiscal injections of oxygen-ozone ${ }^{20}$. The first suggestion of using tomographies to guide needle introduction was made in 1998, by Muto et al. ${ }^{22}$.

Several studies were published between 1989 and 2018 on the use of percutaneous injections of ozonotherapy for lumbar pain, and good efficacy and safety were observed, with an efficacy rate of $70-90 \%{ }^{20.21}$. 


\section{TYPES OF ADMINISTRATION, DOSES, AND CONCENTRATIONS}

Ozone can be administered as a gas mixture of oxygen-ozone (medical-grade ozone), with a concentration between 10 and $40 \mu \mathrm{g} / \mathrm{mL}^{23-26}$. However, a study on the therapy with low $(10 \mu \mathrm{g} / \mathrm{mL})$, medium $(40 \mu \mathrm{g} / \mathrm{mL})$, and high $(60 \mu \mathrm{g} / \mathrm{mL})$ concentrations in patients with disc herniation showed a higher rate of decline in the group who received a volume of $40 \mu \mathrm{g} / \mathrm{ml}^{25.26}$. Table $1 \mathrm{sum}-$ marizes the studies considered for long-term results.

The richest concentrations, which do not exceed a total of $5 \%$ of the total in ozone, are used in disc herniations ${ }^{2,3,24}$, and the intramuscular, intradiscal, intraforaminal, and periradicular routes are very widespread in Europe $\mathrm{e}^{2,24,27,30}$. Table 2 summarizes the application in various musculoskeletal diseases.

In disc diseases, the procedure is guided by computed tomography (CT) to avoid errors in the application and serious complications, and it must be accompanied by an anesthesiologist. However, intramuscular administration in the paravertebral lumbar muscles, bilaterally, with 10 to $20 \mathrm{ml}$ on each side, using the lateral extraspinal approach, with asepsis prior to the procedure using $2 \%$ lidocaine and not exceeding 15 seconds in the time for injection, does not require the use of radiology since it is a simple procedure $^{23.29}$.

In all other routes, it is essential to be guided by CT, and they differ from the previously mentioned procedure since route used is towards the center of the disc by a posterior-lateral approach using a $10 \mathrm{ml}$ oxygen-ozone mixture injection. Subsequently, the needle is redirected to the epidural space, where the tip of the needle should be in the middle point of the intervertebral foramen under lateral view and in the inner margin of the pedicle under anteroposterior view. Still using radiographic imaging, then another $10 \mathrm{ml}$ are injected in the foramen space ${ }^{31}$.

\section{MECHANISM OF ACTION}

Its use, in pain management, is based on the exploitation of the chemical properties of ozone (Figure 1) acquired from the unstable quality of oxygen, which allows the formation of one or more different simple substances and their direct (mechanical) and indirect (anti-inflammatory) effects $\mathbf{s}^{1,23,29,31}$.

The first consists of the destruction of the disc

TABLE 1. PAPERS PUBLISHED REPORTING LONG-TERM RESULTS.

\begin{tabular}{|c|c|c|c|c|c|}
\hline STUDY GROUP & $\begin{array}{l}\text { YEAR OF } \\
\text { PUBLICATION }\end{array}$ & $\begin{array}{l}\text { PATIENTS } \\
\text { ENROLLED }\end{array}$ & PROCEDURE & FOLLOW-UP TIME & $\begin{array}{l}\text { CONCENTRATION } \\
\text { USED IN THE STUDY }\end{array}$ \\
\hline Niu et al 25 & 2018 & 80 & Paravertebral intramuscular & 1 year & $\begin{array}{l}20 \text { pg/ml in Group B, } 40 \\
\text { pg/ ml in Group C, and } \\
60 \text { pg/ml in Group D }\end{array}$ \\
\hline Hosseini et al ${ }^{26}$ & 2019 & 128 & Paravertebral intramuscular & 1 year & 29 to $32 \mathrm{pg} / \mathrm{ml}$ \\
\hline Biazzo et al ${ }^{23}$ & 2018 & 109 & Paravertebral intramuscular & 4 years & $27 \mathrm{pg} / \mathrm{ml}$ \\
\hline Bhatia et al ${ }^{27}$ & 2019 & 500 & $\begin{array}{l}\text { Percutaneous injection to the } \\
\text { nucleus pulposus }\end{array}$ & 1 years & $30 \mathrm{pg} / \mathrm{ml}$ \\
\hline Barbosa et al ${ }^{3}$ & 2017 & 19 & Epiduroscopy & 1 year & $30 \mathrm{pg} / \mathrm{ml}$ \\
\hline Bonetti et al ${ }^{28}$ & 2016 & 84 & Intraforamen & 13 years & $25 \mathrm{pg} / \mathrm{ml}$ \\
\hline Apuzzo et al ${ }^{\mathbf{1 1}}$ & 2014 & 923 & Paravertebral intramuscular & 12 years & $20 \mathrm{pg} / \mathrm{ml}$ \\
\hline Paoloni et al ${ }^{29}$ & 2009 & 327 & Paravertebral intramuscular & 2 years & $20 \mathrm{pg} / \mathrm{ml}$ \\
\hline
\end{tabular}

TABLE 2. SUMMARY OF APPLICATIONS IN SEVERAL MUSCULOSKELETAL DISEASES.

\begin{tabular}{l|l|l|l}
$\begin{array}{l}\text { MUSCULOSKELETAL } \\
\text { DISEASES }\end{array}$ & ADMINISTRATION & DOSAGE & CONCENTRATION \\
\hline Lower back pain & Paravertebral Intramuscular & 10 to $20 \mathrm{ml}$ on each side & $40 \mathrm{pg} / \mathrm{ml}$ \\
\hline Herniated disc & Intradiscal injection & $10 \mathrm{ml}$ & $40 \mathrm{pg} / \mathrm{ml}$ \\
\hline Shoulder (glenohumeral joint) & $\begin{array}{l}\text { Injection with a posterior approach laterally } \\
\text { under the lower margin }\end{array}$ & $10 \mathrm{ml}$ & $15 \mathrm{pg} / \mathrm{ml}$ \\
\hline Hip bursitis (inflammation) & $\begin{array}{l}\text { Injection with a lateral approach with an } \\
\text { infiltration method called peritrochanteric. }\end{array}$ & $10 \mathrm{~m} 15 \mathrm{ml}$ & $25 \mathrm{pg} / \mathrm{ml}$ \\
\hline Osteoarthritis (OA) (knee) & $\begin{array}{l}\text { Variable approach, predominantly external/ } \\
\text { internal lateral parapatellar }\end{array}$ & 5 to $20 \mathrm{ml}$ & $15 \mathrm{to} 40 \mathrm{pg} / \mathrm{ml}$ \\
\hline Cervical herniated disc & Intradiscal injection & $5 \mathrm{ml}$ & $20 \mathrm{pg} / \mathrm{ml}$ \\
\hline
\end{tabular}




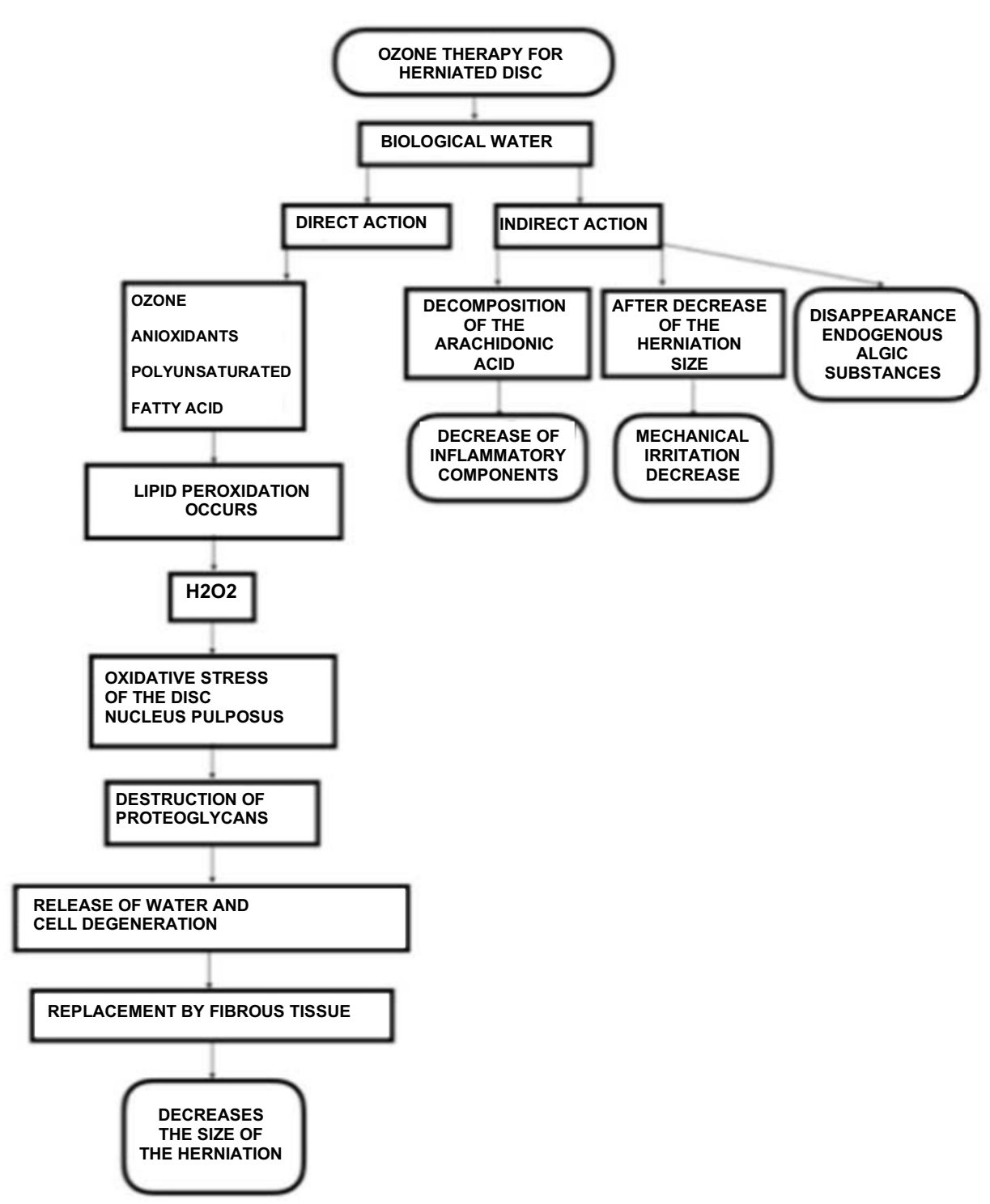

nucleus pulposus components, resulting in a release of water molecules and the subsequent cellular degeneration of the matrix, which is then replaced by fibrous tissue, leading to a reduced disc volume 24,27,28,32 $^{\text {. }}$

The ozone reacts with the antioxidants and polyunsaturated fatty acids (PUFAs) present. Lipidic peroxidation leads to the simultaneous formation of reactive oxygen species (ROS) and lipid oxidative products $(\mathrm{LOPs})^{25}$.

One of the ROS is hydrogen peroxide $\left(\mathrm{H}_{2} \mathrm{O}_{2}\right)$, a non-radical oxidant capable of acting as an ozone messenger, responsible for causing several biological and therapeutic effects ${ }^{25}$.

The production of LOP follows the peroxidation of polyunsaturated fatty acids (PUFAs). They are inherently toxic and should be generated at very low concentrations ${ }^{28}$.
The ozone reacts as soon as it is dissolved in biological water (the nucleus pulposus is located in the central disc has a gelatinous water content of approximately $75 \%$ to $80 \%$ ), causing an oxidant action and decomposing some of the glycosaminoglycans chains in the nucleus, reducing its ability to retain water, decreasing the size of the herniation and, subsequently, contributing to reducing the impact of the herniation on the venous and arterial flow, causing hyperoxygenation ${ }^{11,25,33}$.

The indirect effect is perceived by modifying the decomposition of arachidonic acid in inflammatory prostaglandins. As a result, there is a decrease in inflammatory components and pain regression ${ }^{8,27,29}$. In addition, the disappearance of the herniated material decreases mechanical irritation, reducing axon sensitivity. On the other hand, endogenous analgesic 
substances released during perineural ischemia or neural inflammation present in the spinal ganglion and nerve roots that can stimulate the nociceptors cease to exist ${ }^{3}$.

A recent study has raised the hypothesis that after the administration of percutaneous injections humoral immunity is suppressed, leading to low levels of IgG and IgM. Consequently, the pain score in the Visual Analog Scale (VAS), which uses a $10 \mathrm{~cm}$ ruler and a 10-point scale, with zero indicating no pain and 10 the most severe pain, in addition to intermediate scores from 1 to 3 , which indicate mild pain, and 4 to 6 , which indicate moderate pain that affects sleep. However, its validation was limited by the short follow-up period of only 12 months, indicating that in order to subscribe to his theory, the long-term effectiveness requires further studies ${ }^{25}$

\section{COMPLICATIONS}

Due to its improper use by charlatans and unprepared doctors, erroneous indications in the recent past have made its use dangerous, thus contributing to a bad reputation of the therapy ${ }^{5.19}$, causing some states of the United States ${ }^{7.19}$, as well as in Brasil ${ }^{7}$, to withdraw permissions of its use. Therefore, it is vital to know possible complications.

However infrequent, and even considering the absence of adverse effects when using the concentrations already mentioned in this article, complications should be considered, such as: thunderclap headaches due to pneumocephalus, with only three cases reported in the literature ${ }^{14.23}$; Anton Syndrome, only three cases up until now ${ }^{6}$; reduction of visual acuity; vitreous hemorrhage; subcutaneous hematoma; syncope; air embolism; vertebrobasilar ischemic cerebral accident; pyogenic discitis; lesion to the dorsal and ventral root, causing sciatic pain; and local infection due to lack of proper hygiene and asepsis, 3,15,34-36.

\section{FINAL CONSIDERATIONS}

The literature confirms that, in clinical practice, it is safe to use oxygen-ozone therapy through percutaneous injections for the treatment of lumbar pain, particularly when compared to surgery and drug therapy ${ }^{31}$. The complications are minimal, provided the strict criteria in the patient selection are followed, with the presence of disc herniations visualized by computed tomography or guided by fluoroscopy, with an accurate diagnosis of spinal level, and trained and experienced physicians to perform the procedure, except for the intramuscular approach. It is also required to use the correct dosage of ozone, and follow-up after the procedure must be conducted by a neuroradiologist ${ }^{3,7,28,33,37}$.

\section{CONCLUSION}

We conclude that minimally invasive therapy with oxygen-ozone and its minor complications or side effects make this procedure effective and with a favorable analgesic profile. However, it is necessary to draw up medical guidelines to assist in strict control and systematic procedures, thus avoiding damage to patients, since we could not find any in the publications analyzed.

\section{Conflicts of interest}

The authors declare there are no conflicts of interest in the present paper.

\section{Author's Contribution}

Luciano Timbó Barbosa: Assessment and selection of papers and preparation of the manuscript.

Célio Fernando de Sousa Rodrigues: Assessment and correction of the manuscript.

Raul Ribeiro de Andrade: Assessment and selection of papers. Fabiano Timbó Barbosa: Assessment and correction of the manuscript.

\section{RESUMO}

INTRODUÇÃO: Dor lombar é um dos principais motivos de consultas médicas, provocando afastamento das rotinas diárias, por ser incapacitante, resultando em danos sociais e pessoais. Dentre os tratamentos complementares, a ozonioterapia oferece analgesia para a maioria dos pacientes e com mínimos relatos de complicações. Entretanto, grandes questionamentos sobre sua efetividade clínica ainda não foram respondidos, além de haver relatos de complicações graves.

OBJETIVO: Descrever o uso da ozonioterapia no tratamento da dor lombar, enfocando seus efeitos favoráveis e desfavoráveis, e seu perfil analgésico.

MÉTODOS: Foi realizada uma pesquisa bibliográfica transversal com artigos científicos obtidos das bases de dados PubMed, Lilacs e Scopus, utilizando os descritores: "Ozônio", "Terapia", "Dor lombar", "Complicação", "Hérnia de Disco","Diretriz", "Protocolo", "Padrões", "Critérios". 
RESULTADOS: A literatura pesquisada corrobora que, na prática clínica, há segurança na utilização da terapia com a mistura oxigênio-ozônio por meio de injeções percutâneas para o tratamento de dor lombar, principalmente quando comparada às cirurgias e ao uso de medicamentos, desde que sejam seguidos critérios rígidos.

CONCLUSÃo: O procedimento é efetivo e tem perfil analgésico favorável. No entanto, é necessária a confecção de uma diretriz médica que auxiliará no controle rígido e sistemático do mesmo.

PALAVRAS-ChaVe: Ozônio/uso terapêutico. Dor lombar. Compressão da medula espinal. Deslocamento do disco intervertebral.

\section{REFERENCES}

1. Magalhães FN, Dotta L, Sasse A, Teixeira MJ, Fonoff ET. Ozone therapy as a treatment for low back pain secondary to herniated disc: a systematic review and meta-analysis of randomized controlled trials. Pain Physician. 2012;15(2):E115-29.

2. Oliveira Junior JOO, Lages GV. Ozonioterapia em lombociatalgia. Rev Dor. 2012;13(3):261-70

3. Barbosa DC, Ângelos (SD, Macena GM|, Magalhães FNO, Fonoff ET. Effects of ozone on the pain and disability in patients with failed back surgery syndrome. Rev Assoc Med Bras. 2017;63(4):355-60.

4. Brasil. Câmara dos Deputados. Projeto de Lei PL 9.001/2017. Autoriza a Lei n. 227, de 01 de novembro de 2017 que dispõe sobre a prescrição da ozonioterapia em todo o território nacional. [cited 2018 May 15]. Available from: <http://www.camara.gov.br/proposicoesWeb/ fichadetramitacao?idProposicao=2160126>

5. Dall'Olio M, Princiotta C, Cirillo L, Budai C, Santis F, Bartolini S, et al. Oxygen-ozone therapy for herniated lumbar disc in patients with subacute partial motor weakness due to nerve root compression. Interv Neuroradiol. 2014;20(5):547-54

6. Vaiano AS, Valente C, Benedetti G, Caramello G. Transient cortical blindness after intradiscal oxygen-ozone therapy. Indian | Ophthalmol. 2016;64(12):944-6

7. Conselho Federal de Medicina. Nota de repúdio ao PL que autoriza a ozonioterapia, Projeto de Lei 9.001, de 01 de novembro de 2017. [cited 2018 May 15]. Available from: http://portal.cfm.org.br/index.php?option=com_content $\&$ view=article \&id=27338:2017-12-15-18-29-3 9\&catid=3:portal>

8. Seyam O, Smith NL, Reid I, Gandhi J, Jiang W, Khan SA. Clinical utility of ozone therapy for musculoskeletal disorders. Med Gas Res. 2018;8(3):103-10.

9. Latini E, Curci ER, Massimiani A, Nusca SM, Santoboni F, Trischitta D, et al. Ultrasonography for oxygen-ozone therapy in musculoskeletal diseases. Med Gas Res. 2019;9(1):18-23.

10. Costa T, Rodrigues-Manica S, Lopes C, Gomes |, Marona |, Falcão S, et al. Ozonoterapia na osteoartrose do joelho: revisão. Acta Med Port. 2018;31(10):576-80.

11. Apuzzo D, Giotti C, Pasqualetti P, Ferrazza P, Soldati P, Zucco GM. An observational retrospective/horizontal study to compare oxygen-ozone therapy and/or global postural re-education in complicated chronic low back pain. Funct Neurol. 2014;29(1):31-9.

12. Das G, Ray S, Ishwarari S, Roy M, Ghosh P. Ozone nucleolysis for management of pain and disability in prolapsed lumber intervertebral disc. Interv Neuroradiol. 2009;15(3):330-4.

13. Sagai M, Bocci V. Mechanisms of action involved in ozone therapy: is healing induced via a mild oxidative stress? Med Gas Res. 2011;1:29.

14. Braidy V, Izadi M, Sureda A, Jonaidi-Jafari N, Banki A, Nabavi SF, et al. Therapeutic relevance of ozone therapy in degenerative diseases: focus on diabetes and spinal pain. J Cell Physiol. 2018;233(4):2705-14.

15. Liu H, Wang Y, An J, Williams JP, Cope DK. Thunderclap headache caused by an inadvertent epidural puncture during oxygen-ozone therapy for patient with cervical disc herniation. Chin Med J (Engl). 2016;129(4):498-9.

16. Oliveira ARM, Wosch CL. Ozonólise: a busca por um mecanismo. Quim Nova. 2012;35(7):1482-5.

17. Rubin MB. The history of ozone. The Schönbein period, 1839-1868. Bull Hist Chem. 2001;26(1):40-56.

18. Peres LV. Monitoramento da coluna total de ozônio e a ocorrência de eventos de influência do buraco de ozônio antártico sobre o sul do Brasil. [Tese de Doutorado]. Santa Maria: Universidade Federal de Santa Maria; 2016.

19. Bocci V. Ozone as Janus: this controversial gas can be either toxic or medically useful. Mediators Inflamm. 2004;13(1):3-11.

20. Verga C. Nuovo approccio terapeutico alle ernie e protrusioni discali lombari. Riv Neuroradiol. 1989;2(1 suppl.):148.

21. Fabris G, Tommasini G, Lavaroni A, Biasizzo E, Petralia B, Aprile I, et al. Percutaneous treatment of lumbar herniated disc: 10 years of experience in Udine. Riv Neuroradiol. 1997;10:523-32.

22. Muto M, Avella F. Percutaneous treatment of herniated lumbar disc by intradiscal oxygen-ozone injection. Interv Neuroradiol. 1998;4(4):279-86.

23. Biazzo A, Corriero AS, Confalonieri N. Intramuscular oxygen-ozone therapy in the treatment of low back pain. Acta Biomed. 2018;89(1):41-6.

24. Beyaz SG, Altaş C, Sayhan H. Cardiopulmonary arrest and pneumoencephaly developing after epidural oxygen: ozone mixture therapy. Anesth Essays Res. 2018;12(1):285-7.

25. Niu T, Lv C, Yi G, Tang H, Gong C, Niu S. Therapeutic effect of medical ozone on lumbar disc herniation. Med Sci Monit. 2018;3(24):1962-9.

26. Hosseini B, Taheri M, Sheibani K. Comparing the results of intradiscal ozone injection to treat different types of intervertebral disc herniation based on MSU classification. Interv Neuroradiol. 2019;25(1):111-6.

27. Bhatia A, Munk P, Lee D, Elias G, Murphy K. Percutaneous ozone treatment for herniated lumbar discs: 1-year follow-up of a multicenter pilot study of a handheld disposable ozone-generating device. J Vasc Interv Radiol. 2019;30(5):752-60.

28. Bonetti $M$, Zambello A, Leonardi M, Princiotta C. Herniated disks unchanged over time: size reduced after oxygen-ozone therapy. Interv Neuroradiol. 2016;22(4):466-72.

29. Paoloni M, Di Sante L, Cacchio A, Apuzzo D, Marotta S, Razzano M, et al. Intramuscular oxygen-ozone therapy in the treatment of acute back pain with lumbar disc herniation: a multicenter, randomized, double-blind, clinical trial of active and simulated lumbar paravertebral injection. Spine. 2009;34(13):1337-44.

30. Beyaz SG, Sayhan H. Six-month results of cervical intradiscal oxygen-ozone mixture therapy on patients with neck pain: preliminary findings. Pain Physician. 2018;21(4):E449-56.

31. Zhang Y, Ma Y, Jiang J, Ding T, Wang |. Treatment of the lumbar disc herniation with intradiscal and intraforaminal injection of oxygen-ozone. J Back Musculoskelet Rehabil. 2013;26(3):317-22.

32. Andreula CF, Simonetti L, De Santis F, Agati R, Ricci R, Leorardi M. Minimally invasive oxygen-ozone therapy for lumbar disk herniation. AJNR Am J Neuroradiol. 2013;24(5):996-1000.

33. Giurazza F, Guarnieri G, Murphy KJ, Muto M. Intradiscal $\mathrm{O}_{2} \mathrm{O}_{3}$ : rationale, injection technique, short- and long-term outcomes for the treatment of low back pain due to disc herniation. Can Assoc Radiol J. 2017;68(2):171-7.

34. Re L, Rowen R, Travagli V. Ozone therapy and its use in medicine. Cardiology. 2016;134(2):99-100

35. Pellicanò G, Martinelli F, Tavanti V, Bonetti M, Leonardi M, Muto M, et al. The Italian Oxygen-Ozone Therapy Federation (FIO) study on oxygen-ozone treatment of herniated disc. Int J Ozone Therapy. 2007;6(1):7-15.

36. Seyman D, Ozen NS, Iran D, Ongut G, Ogunc D. Pseudomonas aeruginosa septic arthritis of knee after intra-articular ozone injection. New Microbiol. 2011;35(3):345-8.

37. Muto M, Andreula C, Leonardi M. Treatment of herniated lumbar disc by intradiscal and intraforaminal oxygen-ozone (O2-O3) injection. J Neuroradiol. 2004;31(3):183-9. 